\title{
Chemical Composition and Anti-Insecticidal Activity of the Essential Oils of Thymus of Morocco: Thymus capitates, Thymus Bleicherianus and Thymus Satureioides
}

\author{
Ayoub Ainane ${ }^{1}$, Fatima Khammour ${ }^{1}$, Sanaa Charaf ${ }^{1}$, Meriem Elabboubi ${ }^{1}$, Laila Bennani ${ }^{1}$, M'hamed El Kouali $^{1}$, \\ Mohammed Talbi ${ }^{1}$, Sanaa Cherroud ${ }^{2}$, El Hassan Abba ${ }^{2}$ and Tarik Ainane ${ }^{2}$ \\ ${ }^{1}$ Laboratory of Analytical Chemistry and Physical Chemistry of Materials, Faculty of Sciences Ben Msik, University of Hassan II, Morocco \\ ${ }^{2}$ Superior School of Technology - Khenifra (EST-Khenifra), University of Moulay Ismail, Morocco
}

Submission:March 27, 2018; Published:April 09, 2018

"Corresponding author:Tarik Ainane, Superior School of Technology - Khenifra (EST-Khenifra), University of Moulay Ismail, PB 170, Khenifra, Morocco, Tel: +212 (0) 634576500; Email: ainane@gmail.com

\begin{abstract}
Aromatic plants have an increasing advantage thanks to the valorization of their essential oils in various applications, such as antimicrobial, antifungal, antibacterial, antitoxic, insecticidal and insect repellent, etc. This work reports the valorization, as a bio insecticide, of the essential oils of three Moroccan species of thyme that belongs to the family of Lamiaceae: Thymus bleicherianus (TB), Thymus capitatus (TC) and Thymus saturioides (TS) extracted by hydro distillation and analyzed by gas chromatography-mass spectrometry (GC-MS). Thymol, $\beta$-Ocymene, Camphor and o-Cymene were obtained as majority compounds, with a percentage of $79.57 \%$ in the essential oil of Thymus bleicherianus (TB). The essential oil of Thymus capitatus (TC) is characterized by the presence of carvacrol and $\alpha$-Terpinene as main chemical constituents with a percentage of $76.51 \%$, and as well as the main essential oil compounds of Thymus satureioides (TS) are: Thymol, $\alpha$-Terpinene, E- $\beta$-Ocymene, Camphor, and Borneol with a percentage of $74.79 \%$.The chemical composition varies quantitatively and qualitatively according to the species studied, the yields obtained respectively from Thymus bleicherianus (TB), Thymus capitatus (TC) and Thymus satureioides (TS) are: $1.71 \% ; 1.43 \%$ and $0.69 \%$. Susceptibility tests carried out under laboratory conditions against the wheat pest sitophilus oryzae, this bio activity is mainly due to the richness of these species in carvacrol and thymol which are known for their effectiveness against pests.
\end{abstract}

\section{Introduction}

Pests are a serious problem in grains during storage and its derived industry [1]. Indeed, according to Scherrer [2], Morocco is one of the Mediterranean countries with a long medical tradition and traditional know-how based on medicinal plants. In addition, Thymus is one of the most important genera in number of species in the family Lamiaceae (lamiaceae) including about 215 species [3], and includes many varieties. In Morocco, the species of the genus Thymus (from the Greek name: Thumos, coming from the Greek word (theo) perfume or fragrant plant) have several nominations (in Amazigh: Azukni, Tazuknite, in Arabic: Ziitra) and represented by 21 species including 12 endemic [4]. The aromatic and medicinal properties of thymus are of great importance, since its essential oil is endowed with antibacterial, antifungal and insecticidal activities. ; and as a result he made one of the most popular plants in the world. The objective of this work is the characterization of the chemical composition of the essential oils of Thymus bleicherianus (TB), Thymus capitatus (TC) and Thymus saturioides (TS), and the study of the insecticidal activity of the essential oils of these three species of thyme vis-à-vis the wheat pest sitophilus oryzae.

\section{Material and Methods}

\section{Plant Material}

Thymus Bleicherianus (TB): Thymus bleicherianus is a species of North Africa. It is endemic to Morocco and Algeria. In Morocco, this species develops in the thermo-Mediterranean stage, in temperate and hot semi-arid and subhumid bioclimates. It is found in the regions of Meknes and Oujda (Tafogalt Forest), respectively in central and eastern Morocco [5]. 
Thymus Capitatus (TC): Thymus capitatus is a species of the Mediterranean basin. In Morocco, it is found in the south and west of the city of Tetouan (northern Morocco), in the temperate bioclimate; it develops in the floor of thermo-Mediterranean vegetation [6].

Thymus Satureioides (TS): The Thymus satureioides It is an upright shrub, up to $60 \mathrm{~cm}$ tall with many branches. The leaves are spatulate, the inflorescence in loose glomeruli, the corolla is pink or pale pink. The Thymus satureioides is an endemic species of Morocco. It is widespread in forest clearings, scrub and matorrals of low and medium mountains up to $2200 \mathrm{~m}$ altitude, on siliceous limestone substrates and rocky soils more or less earthy but well drained [7].

\section{Collection of Samples}

Specimens from the aerial part (stems, leaves and flowers) of Thymus bleicherianus (TB), Thymus capitatus (TC) and Thymus satureioides (TS) were harvested from cooperatives in August (2017) respectively in the regions of Meknes (central Morocco), Tetouan (northern Morocco) and Agadir (south-west). These three species have been verified by a botanist at Forest Research Center, Kenifra, Morocco.

\section{Extraction of Essential Oil}

The collected samples are dried for ten days in the open air and in the shade. Extraction of the HE from these samples was performed by hydro-distillation in a Clevenger type apparatus. Three distillations were carried out for each sample, for three hours, of $250 \mathrm{~g}$ of the aerial part (stems, leaves and flowers) dried, with 11 of water in a flask surmounted by a column and a refrigerant, the species less dense water are collected by simple decantation and dried over anhydrous sodium sulphate $\left(\mathrm{Na}_{2} \mathrm{SO}_{4}\right)$ before analysis.

\section{Performance Calculation}

The yield of essential oil (expressed as a percentage) is calculated by the ratio between the weight of the oil extracted and the weight of the plant material used [8]. The yield of essential oil was determined relative to the dry matter, evaluated from $100 \mathrm{~g}$ dried in an oven for $48 \mathrm{~h}$ at $60{ }^{\circ} \mathrm{C}$. The essential oil obtained is stored at a temperature of $4{ }^{\circ} \mathrm{C}$ in the dark.

$$
\operatorname{Yield}(\%)=\left(\frac{\mathrm{V}}{\mathrm{ms}} \times 100\right) \pm\left(\frac{\Delta \mathrm{V}}{\mathrm{ms}} \times 100\right)
$$

$\mathrm{V}$ : volume of essential oil collected; $\Delta \mathrm{V}$ : error on reading; ms: mass of vegetable matter in the dry state.

\section{Gas Chromatography (GC) / Mass Spectrometry (MS)}

The analysis of the essential oils was carried out by gas chromatography coupled with mass spectrometry (GC-MS). Coupling was performed on a Hewlett-Packard model 5970 (quadrupole detection system), equipped with a fused silica capillary column of $2 \mathrm{~mm} \times 0.23 \mathrm{~mm}$ DB1 type; temperature programming from $50^{\circ} \mathrm{C}$ to $200^{\circ} \mathrm{C}$, with a gradient of $5^{\circ} \mathrm{C} \mathrm{min}^{-1}$.
The retention indices were determined by gas chromatography on two fused silica capillary columns $(25 \mathrm{~m} \times 0.25 \mathrm{~mm})$ of the type OV-101 and Cabowax $20 \mathrm{M}$, with temperature programming identical to that used for the coupling. (Shimatzu GC-14A equipped with a flame ionization detector and a C-R4A model integrator).

\section{Insecticide Tests}

The wheat weevil sitophilus oryzae is a species of Coleoptera insects of the family Curculionidae and one of the pests of the infestation and destruction of stored grain. The insects studied: The wheat weevil sitophilus oryzae is a species of Coleoptera insects of the family Curculionidae and one of the pests of the infestation and destruction of stored grain. The insects were raised on soft wheat in one-liter capacity plastic boxes, transparent and screened. The whole is placed in an enclosure whose temperature is $30^{\circ} \mathrm{C}$ and the relative humidity is $70 \%$. The insecticidal tests used in this study are those reported by Hamraoui and Regnault-Roger [9]; in an experimental chamber containing twenty insects, the essential oils in increasing concentrations from $1.7 \times 10^{-2} \mu \mathrm{l} / \mathrm{cm}^{3}$ to $12 \times 10^{-2} \mu \mathrm{l}$ / $\mathrm{cm}^{3}$ on Whatman \# 1 paper. The assembly is introduced into a fumigation chamber included in the experimental chamber (semi-ventilated). Three repetitions were performed for each concentration. The number of dead insects is recorded after 1 day, then living insects are placed in $40 \mathrm{~g}$ of wheat grains and the count of dead adults is done after 5 days. Corrected mortality in treated insects is expressed according to Abbot's formula.

$$
L C=\left(\frac{(L 0-L 1)}{(100-L 1)} X 100\right)
$$

LC = Corrected Mortality; L0 = Mortality observed in insects; L1 = Mortality observed in controls.

\section{Results and Discussion}

\section{Yields of Essential Oils}

The average yield of essential oil of each species was calculated according to the dry plant material obtained from the aerial parts (stems, leaves and flowers) of the plants studied. The yield of essential oil obtained is given in Table 1. The average yields of essential oils were calculated according to the dry plant matter of the aerial part of the plant. Thymus bleicherianus (TB) samples yielded a rate of approximately 1.71\% higher than that obtained from Thymus capitatus (TC) which is $1.43 \%$, and Thymus saturated (TS) which is $0.69 \%$. The rate of Thymus bleicherianus (TB) is almost identical to that obtained by El Ajjouri M [5] against the Thymus capitatus (TC) is lower and that is respectively $1.75 \%$ and $2.05 \%$ for the Thymus satureioides (TS) the rate of return obtained by Belmalha S [10] is higher which is $2.71 \%$ therefore it can be concluded that several factors could be at the origin of these variations: the age of the plants $[11,12]$, that of the tree [13], the nature of the soil and the climate $[14,15]$, the part of the plant subject to extraction and the period of harvest. 


\section{Organic and Medicinal Chemistry International Journal}

Table 1: Yield in essential oils.

\begin{tabular}{|c|c|c|}
\hline Sites & Species & Yield \\
\hline Regions of Meknes & Thymus bleicherianus (TB) & $1.71 \%$ \\
\hline Regions of Tetouan & Thymus capitatus (TC) & $1.43 \%$ \\
\hline Regions of Agadir & Thymus satureioides (TS) & $0.69 \%$ \\
\hline
\end{tabular}

\section{Chemical Composition}

The gas chromatographic analysis results coupled with the mass spectrometry of the essential oils of the plants studied are shown in (Table 2). Chromatographic analyzes of essential oils identified 38 compounds which represent approximately (99.1\%) for Thymus bleicherianus (TB), for Thymus capitatus

Table 2: Chemical composition of the essential oils of Thymus capit Thymus bleicherianus (TB), Thymus capitatus (TC) and Thymus saturioides (TS).

\begin{tabular}{|c|c|c|c|}
\hline Identification & Thymus Bleicherianus (TB) & Thymus Capitatus (TC) & Thymus Satureioides (TS) \\
\hline$\gamma$-Terpinène & 1.24 & 0.67 & 1.03 \\
\hline$\alpha$-Terpinène & 3.99 & 10.56 & 5.98 \\
\hline$\alpha$-Ocimene & 0.22 & - & 2.15 \\
\hline Camphène & 1.12 & 0.98 & 0.80 \\
\hline$\beta$-Ocymène & 21.96 & 8.58 & 0.19 \\
\hline$\beta$-Pinène & - & 0.31 & - \\
\hline p-cymène & 1.55 & 2.31 & 0.99 \\
\hline carvacrol & 2.48 & 65.96 & 3.33 \\
\hline$\alpha$-terpinolene & 0.05 & - & 0.16 \\
\hline o-Cymene & 8.65 & 0.41 & 2.06 \\
\hline Limonene & 0.19 & 0.09 & - \\
\hline Eucalyptol & 1.00 & 0.74 & 0.62 \\
\hline Sabinène & 0.03 & 0.42 & - \\
\hline Linalool & 0.09 & 0.02 & 0.10 \\
\hline terpinolene & 0.02 & 0.05 & 0.08 \\
\hline$\beta$-Linalool & 0.46 & 0.33 & - \\
\hline Borneol & 0.86 & 0.65 & 2.80 \\
\hline Terpinène-4-ol & 0.50 & 0.10 & 0.74 \\
\hline 3-cyclohexene-1-carbinol & 0.03 & - & 0.01 \\
\hline$\alpha$-humulène & - & - & 0.44 \\
\hline Thymol méthyle ether & - & 0.04 & 0.02 \\
\hline Isothymol methyl ether & 0.01 & - & 0.21 \\
\hline Thymol & 36.85 & 0.67 & 29.06 \\
\hline E- $\beta$-Ocymène & 1.35 & 1.33 & 11.30 \\
\hline$\alpha$-Bisabolol & 0.21 & - & 0.01 \\
\hline Caryopyllene & 1.06 & 0.16 & 3.29 \\
\hline$\alpha$-Sinensal & 0.01 & 0.09 & - \\
\hline Acétate de bornyle & - & - & 0.05 \\
\hline Geranyl acetate & - & 0.03 & - \\
\hline Copaene & - & 0.01 & - \\
\hline Camphre & 12.11 & 0.85 & 14.64 \\
\hline$\alpha$-Farnese & - & - & 0.09 \\
\hline$\alpha$-Bisabolol & 0.01 & 0.05 & 0.03 \\
\hline
\end{tabular}


Organic and Medicinal Chemistry International Journal

\begin{tabular}{|c|c|c|c|}
\hline Bornéol & 1.40 & 0.99 & 13.81 \\
\hline Myrtenol & 0.05 & - & - \\
\hline$\gamma$-Elemene & - & - & 0.01 \\
\hline Acétate de géranyle & 0.01 & - & - \\
\hline$\alpha$-Copaène & - & 0.11 & - \\
\hline$\beta$-Bourbonéne & 0.01 & 0.03 & 0.01 \\
\hline$\beta$-Elemene & 0.05 & - & 0.09 \\
\hline$\alpha$-Grujunene & 0.01 & - & - \\
\hline$\alpha$-Amorphene & - & 0.06 & 0.01 \\
\hline$\alpha$-Patchoulène & - & 0.05 & - \\
\hline Aromadendrène & 0.05 & 0.05 & - \\
\hline$\beta$-caryophyllène & 1.16 & 0.09 & 3.6 \\
\hline Valencène & - & - & 0.05 \\
\hline Germacréne D & - & 2.73 & 0.13 \\
\hline Eremophilene & 0.40 & - & - \\
\hline Junipène & 0.09 & 0.01 & - \\
\hline$\beta$-himachaléne & 0.06 & 0.01 & 0.01 \\
\hline caryophylléneoxyde & 0.56 & - & 1.99 \\
\hline myrcène & - & - & 0.11 \\
\hline Total & 99.9 & 99.54 & 100 \\
\hline
\end{tabular}

The results of Zayyad N [16], with regard to T bleicherianus, the major compounds are thymol (55.9\%), $\alpha$-terpinene (13.19\%), E- $\beta$-ocymene (10.43\%) and carvacrol $(2.71 \%)$ but $\mathrm{T}$ bleicherianus studied by El Ajjouri M [5], with the major compound $\alpha$-terpinene (42.23\%) followed by thymol $(23.95 \%)$. For the Thymus capitatus. The results of Hilan C [17], carvacrol $(70.92 \%)$ are the predominant compound of gasoline, while the concentration of thymol is $23.9 \%$ in El Ajjouri M [5]. For Thymus capitatus (Tunisia), carvacrol $(68.8 \%)$ is the main component of the oil, followed by p-cymene $(11.1 \%)$ and $\gamma$-terpinene $(8.6 \%)$ [18]. The essential oil of Thymus capitatus from Greece is richer

\section{Biological Tests}

in carvacrol with a higher 80\% [5]. The thymes of Spain, Morocco, Tunisia and Greece are carvacrol chemotype. So the thymes of the region of the Mediterranean basin are carvacrol thymes. The results of the analysis of essential oils of El Ouali Lalami A [19] show that the major components of Thymus satureioides (TS) are p-cymene $(27.59 \%)$ and thymol (14.09\%). Variations in chemotype and chemical polymorphism of essential oils between the three plants may be due to various conditions, environment, genotype, geographical origin, harvest period and vegetative stage of the plant [20].

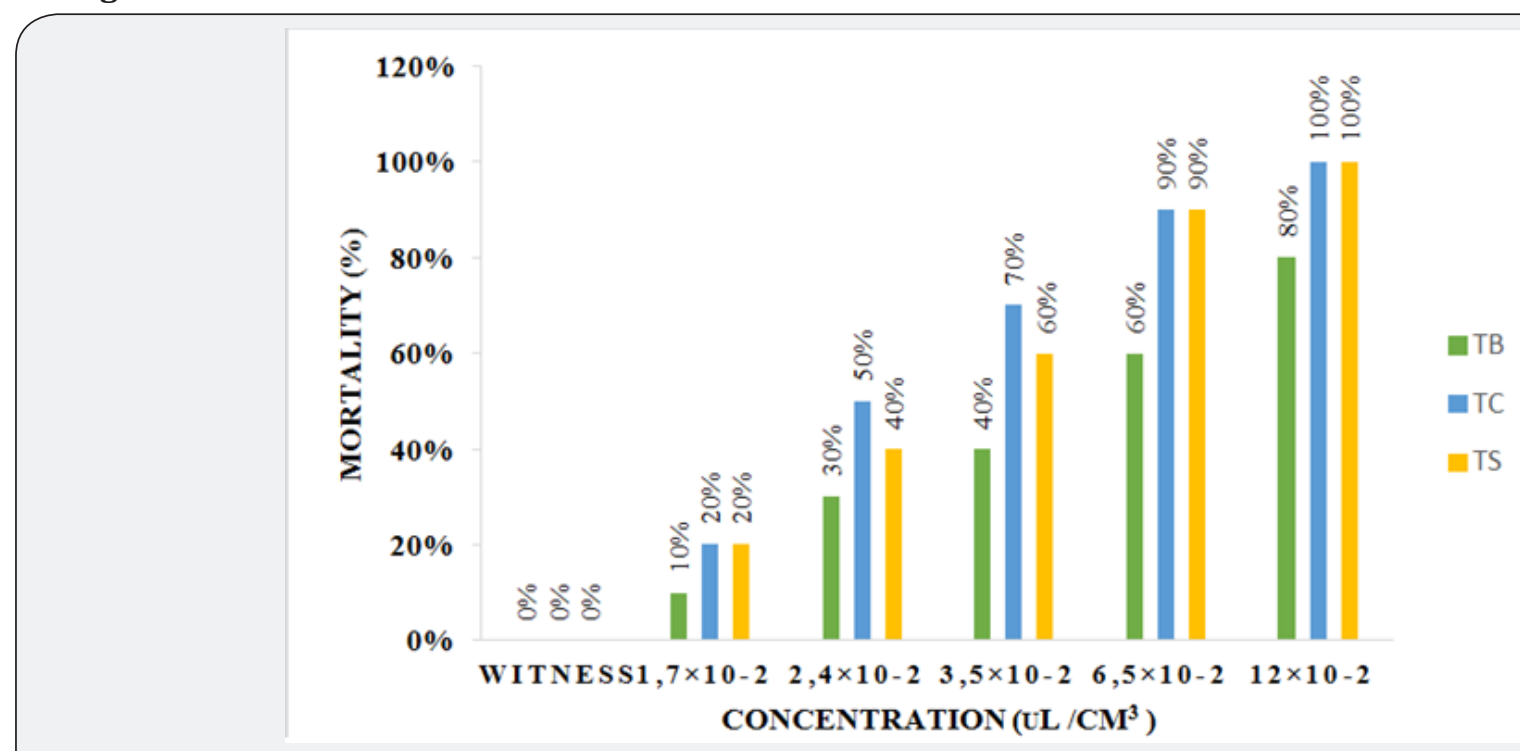

Figure 1: Toxicity of essential oil after 1 day for treatment. 
The insecticidal activity of the essential oils studied against Sitophilus oryzae was evaluated by the Whatman No.1 paper contact toxicity test, the results of the insecticide tests of three essential oils showed a very important insecticidal activity during the first day of treatment (Figure 1). The degree of activity of these essential oils varies according to the species studied. According to (Figure 1), all essential oils tested at concentrations ranging from $1.7 \times 10^{-2} \mu \mathrm{l} / \mathrm{cm}^{3}$ to $12 \times 10^{-2} \mu \mathrm{l} / \mathrm{cm}^{3}$, showed significant toxicity to Sitophilus oryzae adults and clearly see that the higher the concentration increases the toxicity of the essential oil is important.

After a five-day contact (Figure 2), Sitophilus oryzae is completely destroyed at a dose of $2.4 \times 10^{-2} \mu \mathrm{l} / \mathrm{cm}^{3}$ for the three essential oils. This insecticidal activity of essential oils is probably due to the major constituent: Thymol, $\beta$-Ocymene, Camphor and o-Cymene in the essential oil of Thymus bleicherianus (TB) $(79.57 \%)$, carvacrol and $\alpha$-Terpinene in the essential oil of Thymus capitatus (TC) (76.51\%), Thymol , $\alpha$-Terpinene, E- $\beta$ Ocymene, Camphor, and Borneol for the essential oil of Thymus saturioides (TS) (74.79\%). The results obtained show that the essential oils tested have an interesting toxicity against sitophilus oryzae. Several works have demonstrated the insecticidal activity of the essential oils of the species of the genus Thymus vis-à-vis some insect pests of stored foodstuffs, in particular Tribolium castaneum (Herbst.), Sitophilus oryzae (L.) and Rhizopertha dominica $[21,22]$.

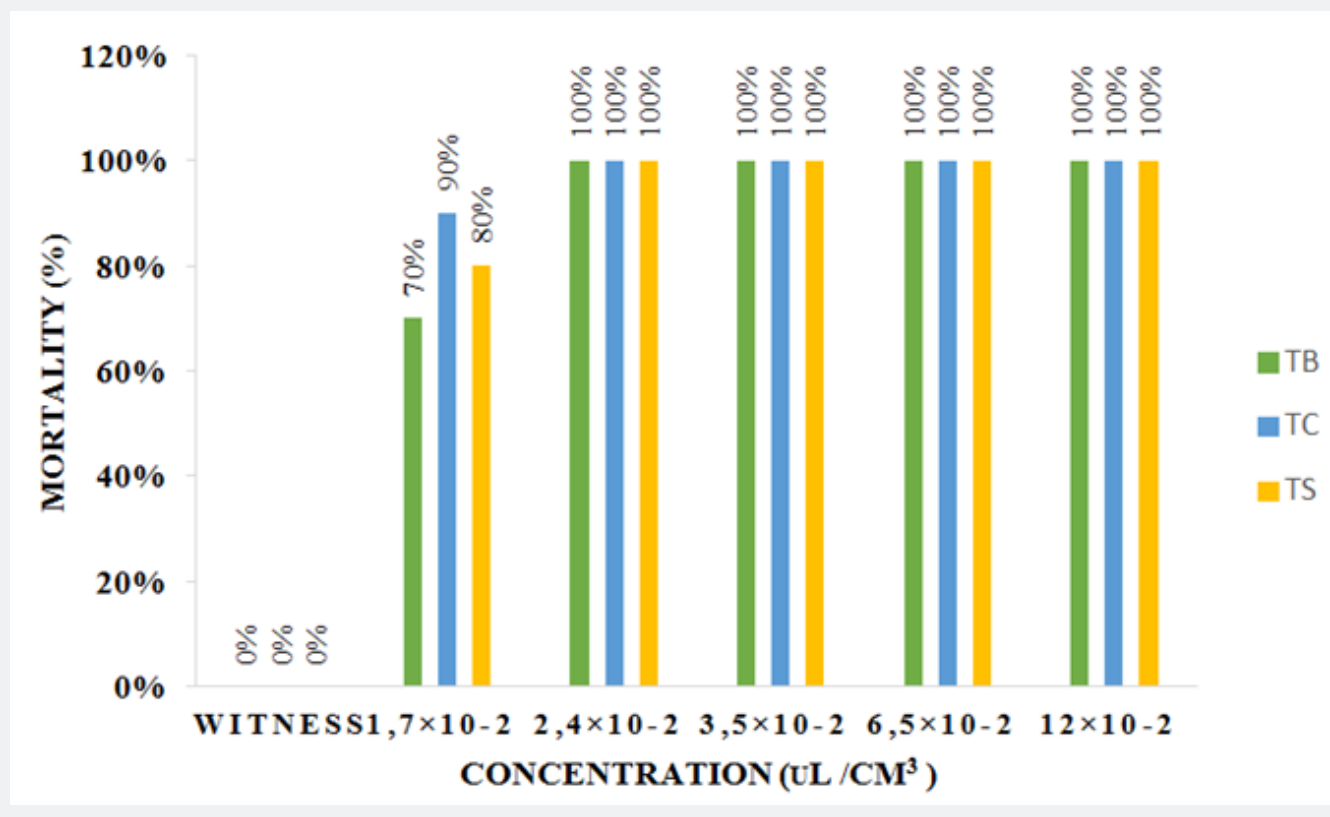

Figure 2: Toxicity of essential oil after 5 days for treatment.

\section{Conclusion}

The yield of essential oil of the plants studied (Thymus bleicherianus (TB), Thymus capitatus (TC) and Thymus satureioides (TS)) is acceptable. The essential oil of Thymus bleicherianus (TB) is rich in Thymol, $\beta$-Ocymene, Camphor and o-Cymene (79.57\%). The most abundant chemical compounds in the essential oil of Thymus capitatus (TC) are carvacrol and $\alpha$-Terpinene $(76.51 \%)$ and for Thymus saturioides (TS) the presence of Thymol, $\alpha$-Terpinene, E- $\beta$-Ocymene, Camphor, and Borneol $(74.79 \%)$. The preliminary results of the insecticide study showed a very important activity for the first day of treatment and the toxicity of the essential oils tested varies widely depending on the nature of the essential oil, the age of the plants, the nature of the soil and the climate and the harvest period.

\section{References}

1. Pérez Mendoza JPW, Flinn JF, Campbell DW, Hagstrum JE, Throne J Econ (2004) Entomol 97: 1474-1483.
2. Scherrer AM, Motti R, Weckerle CS (2005) Traditional plant use in the areas of Monte Vesole and Ascea, Cilento National Park. J Ethnopharmacol 97(1): 129-143.

3. Morales R Thyme (2002) The genus Thymus. The history, botany and taxonomy of the genus Thymus in Stahl Biskup E et Saez F, Thyme. The genus Thymus. Taylor \& Francis, New York, USA.

4. Benabid A (2000) Flore et ecosystems du Maroc, Evaluation et preservation de la biodiversity. Paris : Édition Ibis Press, Italy, pp. 159161.

5. El Ajjouri M (2008) Activity antifongique des huiles essentielles de Thymus bleicherianus Pomel et Thymus capitatus (L) Hoffm \& Link contre les champignons de pourriture du bois dœuvre Biotechnol. Agron Soc Enviro 12(4): 345-351

6. Benabid A (2000) Flore et ecosystems du Maroc Evaluation et preservation de la biodiversité. Paris : Édition Ibis Press, Italy, pp. 159161.

7. Chafai Elalaoui Ali, Boukil Ahmed, Bachar Mohamed, Driss Lkhoumsi et Guermal Abdenasser (2013) Manuel des bonnes pratiques de collecte du thym Centre de Recherche Forestière, HCEFLCD Rabat.

8. Caree P (1953) Précis de technologie et de chimie industrielle. Tome 3, Éditions J B Ballière et fils. 
9. Hamraoui AC, Regnault Roger (1997) Comparaison des activites des monoterpenes sur deux especes dinsectes ravageurs des cultures Ceratitis capita et Rhopalosiphum pad Acta bot Gallica 144 (4): 413417.

10. Saadia Belmalha (june 2015) caracterisation chimique de certaines especes de thym marocain du moyen atlas (region de midelt) chemical characterization of some species of moroccan middle atlas thyme (region of midelt). Global journal of pure and applied chemistry research 3(2): 43-52.

11. Boland IJ, Mancini PME, Glussiani CD, Jourraspe JB (1982) Volatile leaf oil of Eucalyptus delegatensis seedling. Phytochemistry 21(10): 24672469.

12. Chennoufi R, Morizur JP, Richard H, Sandret F (1980) Étude des huiles essentielles d Eucalyptus globulus du Maroc (Feuilles de jeunesse et feuilles adultes) 62(7): 353-357.

13. Zrira S (1992) Les huiles essentielles dEucalyptus du Maroc Facteurs influençant la productivity et la qualité de ces essences, Investigation sur les possibilités dexploitation $\mathrm{dE}$ camaldulensis pour la production d'huile essentielle d'Eucalyptus à cinéole. These Doctorat ès Sci Agron lA V Hassan II Rabat Maroc.

14. Hajji F, El Idrissi A, Fkih Tetouani S, Bellakhdar J (1989) Étude des compositions chimiques de quelques espèces eucalyptus du Maroc. Al Biruniya, Rev Mar Pharm 5(2): 125-132.

15. Sandret FG (1967) Eucalyptus globulus et E cineorifolia pour la production dhuiles essentielles au Maroc. Annales de la recherché forestière au Maroc 9, rapport, 1965: 259-279.
16. Zayyad N (2014) Analyze chimique et activate antibactérienne des huiles essentielles des trois espèces de Thymus: Thymus zygis, T algeriensis et T bleicherianus Bulletin de la Société Royale des Sciences de Liège 83 : 118 -132.

17. christo hilan (2011) chimiotypes de plantes communes au liban du genre origanum et du genre micromeria (lamiaceae) lebanese science journal 12(1).

18. Akrout A, El Jani, H Amouri S, Neffati M (2010) Screening of antiradical and antibacterial activities of essential oil Artemisia campestris L Artemisia herba alba asso \& Thymus capitatus Hoff. \& Link. Growing wild in the South of Tunisia. Science and Technology 2(1): 29-39.

19. El Ouali Lalami A (2013) Composition chimique et activité antibactérienne des huiles essentielles de deux plants aromatiques du centre nord marocain : Thymus vulagris et Thymus satureioïdis LES TECHNOLOGIES DE LABORATOIRE, Volume $8 \mathrm{~N}^{\circ} 31$.

20. Moldão Martins M, Bernardo Gil MG, Beirão Da Costa ML (2002) Sensory and chemical evaluation of Thymus zygis L. essential oil and compressed $\mathrm{CO}_{2}$ extracts. European Food Research and Technology A 214: 207-211.

21. Lee SE, Lee BH, Choi WS (2001) Fumigant toxicity of volatile natural products from Korean spices and medicinal plants towards the rice weevil, Sitophilus oryzae (L). Pest Manag Sci 57(6): 548-553.

22. Jarrahi A, Moharramipour S, Imani S (2012) Chemical composition and fumigant toxicity of essential oil from Thymus carmanicus against two stored product beetles. Mun Ent Zool 7: 215-221.

Your next submission with Juniper Publishers
will reach you the below assets
- Quality Editorial service
- Swift Peer Review
- Reprints availability
- E-prints Service
- Manuscript Podcast for convenient understanding
- Global attainment for your research
- Manuscript accessibility in different formats
( Pdf, E-pub, Full Text, Audio)
- Unceasing customer service
Track the below URL for one-step submission
https://juniperpublishers.com/online-submission.php

